\title{
Potassium Phosphite and Water Deficit: Physiological Response of Eucalyptus Using Multivariate Analysis
}

\author{
Karoline Santos Gonçalves ${ }^{1}$, Vital Pedro da Silva Paz ${ }^{2}$, Fabiane de Lima Silva ${ }^{3}$, Kuang Hongyu ${ }^{4}$ \\ $\&$ Willian Fernandes de Almeida ${ }^{1}$ \\ ${ }^{1}$ Agricultural Engineering Graduate Program, Federal University of Recôncavo da Bahia, Cruz das Almas, Bahia, \\ Brazil \\ ${ }^{2}$ Nucleus of Water and Soil Engineering, Federal University of Recôncavo da Bahia, Cruz das Almas, Bahia, \\ Brazil \\ ${ }^{3}$ Centre of Agrarian, Environmental and Biological Sciences, Federal University of Recôncavo da Bahia, Cruz \\ das Almas, Bahia, Brazil \\ ${ }^{4}$ Department of Statistics, Institute of Exact and Earth Sciences, Federal University of Mato Grosso, Cuiabá, \\ Mato Grosso, Brazil \\ Correspondence: Karoline Santos Gonçalves, Programa de Pós-Graduação em Engenharia Agrícola, \\ Universidade Federal do Recôncavo da Bahia, Cruz das Almas, Bahia, Brazil. Tel: 55-75-3621-2798. E-mail: \\ karolinesg@yahoo.com.br
}

Received: October 24, 2018

Accepted: December 17, $2018 \quad$ Online Published: February 15, 2019

doi:10.5539/jas.v11n3p565

URL: https://doi.org/10.5539/jas.v11n3p565

\begin{abstract}
This study aimed to evaluate the physiological response of Eucalyptus citriodora Hook seedlings subjected to foliar application of potassium phosphite and water deficit with the aid of multivariate statistical analysis, using MANOVA and canonical discriminant analysis. The experiment was conducted in a completely randomized design with five treatments $\left(0.0 \mathrm{~L}\right.$ c.p. ha $^{-1}$ of potassium phosphite with irrigation; $0.0 ; 1.25 ; 2.50$ and $5.00 \mathrm{~L}$ c.p. $\mathrm{ha}^{-1}$ of potassium phosphite without irrigation) and six replicates, in a greenhouse located in the municipality of Cruz das Almas, Bahia, Brazil. Treatments with potassium phosphite were applied by foliar spray, using the commercial product Reforce from Agrichem ${ }^{\circledR}\left(25.0 \% \mathrm{~K}_{2} \mathrm{O}+35.0 \% \mathrm{P}_{2} \mathrm{O}_{5} \mathrm{p} / \mathrm{v}\right)$. Irrigation was suspended seven days after application of the product. The correlation (0.6603) between the evaluated variables indicated that the use of multivariate analysis techniques was adequate to analyze this data set. Eucalyptus plants of the control treatment without irrigation responded to the water deficit conditions with inhibition of photosynthetic activity and increase of free proline content in the leaves. On the other hand, plants which received foliar application of potassium phosphite at highest concentrations $\left(2.50\right.$ and $\left.5.00 \mathrm{~L} \mathrm{c.p.} \mathrm{ha}{ }^{-1}\right)$, even under water deficit conditions, preserved the photosynthetic activity and proline content in the leaves with values equal to those observed in the irrigated control treatment. From this result it is possible to infer about the role of potassium phosphite as an attenuating effect of the water deficit in Eucalyptus citriodora Hook.
\end{abstract}

Keywords: foliar fertilization, canonical discriminant analysis, Eucalyptus citriodora Hook, photosynthesis

\section{Introduction}

The expansion of forests planted with the genus Eucalyptus in Brazil results from a series of factors which favor its large-scale planting, especially its fast growth, high yield and quality of wood, besides being a genus with many species and varieties adapted to the various conditions of climate and soil. Due to these characteristics, eucalyptus has consolidated itself in the Brazilian forestry sector and currently its plantations occupy 5.7 million hectares of the area of planted trees in the country, and a large part is concentrated in the state of Bahia (IBÁ, 2017).

Various fertilizers with the potential to guarantee good adaptation of plants after planting under adverse biotic and abiotic conditions have been studied and used in forest plantations. Among them, foliar fertilizers such as potassium phosphite consisting a source of nutrients that permits to correct nutritional deficiencies, improves the physiological activity of plants, while stimulating the creation of natural mechanisms of defense (N. M. Resende, \& A. Resende, 2005). 
Water restriction and the pressure for priority use of good-quality water have reached several regions of Brazil, limiting agricultural and forestry development. Regarding the production of seedlings of forest species, it is necessary to improve water use efficiency in the nurseries to maintain their quality. Thus, studies involving irrigation and fertilization management are of fundamental importance and have been carried out to increase production, ensuring the survival and initial growth of the seedlings.

Chlorophyll fluorescence parameters have been used to study photosynthesis and in the detection of damage to the photosynthetic apparatus caused by stresses. For being a fast and non-destructive method of evaluation that allows for qualitative and quantitative analysis of the absorption, conversion, transfer and dissipation of light energy at photosystem II (PSII) level, fluorescence can be used as an efficient mechanism for photosynthetic measurements (Martinazzo, Silva, Bianchi, \& Bacarin, 2012).

Given the quantity of fluorescence parameters involved in the photosynthetic process, it is necessary to use statistical techniques that allow the selection of the most important ones in the discrimination of treatments. Among the techniques of exploratory data analysis, the multivariate aim to relate groups of treatments with multiple variables simultaneously, allowing for the reduction in the number of variables capable of explaining the biological phenomenon. In addition, it is able to detect similarities or associations and trend of correlation between variables, as well as identifying the most relevant ones, capable of discriminating groups of treatments (Malaquias et al., 2017).

Different approaches in the field of multivariate analysis permit joint analysis of variables. Multivariate analysis of variance (MANOVA) allows the comparison of means of several independent variables in relation to the groups of treatments, permitting to test the hypothesis that the treatments differ from one another with respect to the multiple variables evaluated (Roy et al., 2009). Already a canonical discriminant analysis (CDA) is a technique that identifies a combination of variables that maximize the Euclidean distance between groups of treatments, minimizing the distance between the experimental units of a specific group of treatments (Stewart, Ivy, \& Anslyn, 2013).

Thus, this study aimed to assess the physiological response of Eucalyptus citriodora Hook seedlings subjected to foliar application of potassium phosphite and to water deficit with the aid of multivariate statistical analysis, applying the techniques of multivariate analysis of variance and canonical discriminant analysis.

\section{Material and Methods}

\subsection{Experimental Location and Design}

The experiment was conducted from April to June 2017, in a greenhouse at the Experimental Area of the Graduate Program in Agricultural Engineering of the Federal University of Recôncavo of Bahia, located in the municipality of Cruz das Almas (BA), Brazil, at geographic coordinates $12^{\circ} 40^{\prime} 12^{\prime \prime} \mathrm{S}, 39^{\circ} 6^{\prime} 7^{\prime \prime} \mathrm{W}$ and altitude of $220 \mathrm{~m}$. The climate of the region, according to the classification of D'Angiolella, Castro Neto, and Coelho (2000), is defined as humid to sub-humid, with mean annual rainfall of $1,143 \mathrm{~mm}$.

The experimental design used was completely randomized, with five treatments $\left(0.0 \mathrm{~L} \mathrm{c.p.} \mathrm{ha} \mathrm{h}^{-1}\right.$ of potassium phosphite with irrigation - control with irrigation; 0.0 L c.p. $\mathrm{ha}^{-1}$ of potassium phosphite without irrigation - control without irrigation; 1.25 L c.p. ha ${ }^{-1}$ of potassium phosphite without irrigation; $2.50 \mathrm{~L} \mathrm{c.p.} \mathrm{ha}{ }^{-1}$ of potassium phosphite without irrigation and $5.00 \mathrm{~L} \mathrm{c.p.}$ ha $^{-1}$ of potassium phosphite without irrigation) and six replicates, totaling 30 experimental plots. Each experimental plot consisted of one Eucalyptus citriodora Hook seedling at the stage of 3 to 4 pairs of leaves, which was transplanted to plastic pot filled with $8 \mathrm{dm}^{3}$ of soil.

The soil used was a cohesive Yellow Latosol with moderate A horizon, with the following chemical characteristics: $\mathrm{pH}$ (water) $=5$; OM $(\%)=1.65$; SB and CEC $\left(\mathrm{cmolc} \mathrm{dm}^{-3}\right)=1.54$ and 4.79 , respectively; and physical characteristics: $776 \mathrm{~g} \mathrm{~kg}^{-1}$ of total sand, $181 \mathrm{~g} \mathrm{~kg}^{-1}$ of clay and $43 \mathrm{~g} \mathrm{~kg}^{-1}$ of silt, corrected with the addition of limestone and fertilizers containing nitrogen, phosphorus and potassium at amounts determined according to the chemical analysis of soil fertility.

After transplanting, the seedlings were kept in greenhouse and regularly irrigated using a water can, at 2-day intervals, maintaining the soil at field capacity.

\subsection{Conduction and Application of Treatments}

Ten days after transplanting, potassium phosphite was applied by foliar spray covering all the shoots, using a handheld $\mathrm{CO}_{2}$-pressurized sprayer operating at constant pressure $\left(3.0 \mathrm{kgf} \mathrm{cm}^{-2}\right)$ and maintained at $0.3 \mathrm{~m}$ distance from the plants. Each treatment received $50 \mathrm{~mL}$ of solution with the specific dose of the commercial product Reforce from Agrichem ${ }^{\circledR}\left(25.0 \% \mathrm{~K}_{2} \mathrm{O}+35.0 \% \mathrm{P}_{2} \mathrm{O}_{5} \mathrm{p} / \mathrm{v}\right)$. 
Irrigation was suspended seven days after application of potassium phosphite. Only in the control with irrigation, plants were irrigated with the volume of water lost by transpiration, determined by the difference between the weight of the pot on the specific day and its initial weight (first day when water deficit was applied). The pots were covered by a plastic bag to avoid water loss by evaporation from the soil and ensure that water consumption was only due to transpiration of the plants.

\subsection{Evaluated Variables}

On the tenth day after imposing water deficit, plants in the control treatment without irrigation exhibited characteristics associated with water stress (wilted leaves), and then chlorophyll a fluorescence was measured in all treatments.

Fluorescence measurements were taken using the portable modulated fluorometer OS5p (Opti-Sciences, Hudson, USA), in the intermediate region of the stem and in the middle region of the leaves, at 9:00 a.m. The potential quantum yield of photosystem II (PSII) was calculated after 30 min of dark adaptation as $F_{v} / F_{m}=\left(F_{m}-F_{0}\right) / F_{m}$, where $\mathrm{F}_{0}$ is the minimum or initial fluorescence, excited by a modulated red light of low intensity $\left(0.03 \mu \mathrm{mol} \mathrm{m}{ }^{-2}\right.$ $\mathrm{s}^{-1}$ ) and $\mathrm{F}_{\mathrm{m}}$ is the maximum fluorescence obtained by the application of a 0.8 -s pulse of saturating actinic light ( $>$ $6000 \mu \mathrm{mol} \mathrm{m} \mathrm{m}^{-2} \mathrm{~s}^{-1}$. The yields of the competitive pathways of de-excitation of the energy absorbed in PSII: effective quantum yield, $\mathrm{Y}_{\mathrm{II}}$; quantum yield of regulated dissipation, $\mathrm{Y}_{\mathrm{NPQ}}$; quantum yield of non-regulated dissipation, $\mathrm{Y}_{\mathrm{NO}}$; were determined according to Kramer, Johnson, Kiirats, and Edwards (2004) and Klughammer \& Schreiber (2008). $\mathrm{Y}_{\mathrm{II}}$ was used to estimate the apparent electron transport rate (ETR) according to the equation: $\mathrm{ETR}=\mathrm{Y}_{\mathrm{II}} \times \mathrm{PFD} \times 0.5 \times 0.84$ (Bilger, Schreiber, \& Bock, 1995), where PFD is the photon flux density $(\mu \mathrm{mol}$ $\left.\mathrm{m}^{-2} \mathrm{~s}^{-1}\right)$ striking the leaf, 0.5 is the value corresponding to the fraction of the excitation energy distributed to PSII, and 0.84 is the value corresponding to the fraction of incident light which is absorbed by the leaves.

After readings of fluorescence, the first pair of fully expanded leaves was collected to analyze the content of free proline. The samples were frozen, lyophilized, ground and stored in ultra-freezer $\left(-80^{\circ} \mathrm{C}\right)$ for subsequent determination. Free proline content in the leaves was quantified by spectrophotometry at $520 \mathrm{~nm}$, using ninhydrin as a specific reagent and pure proline as the standard (Bates, Waldren, \& Teare, 1973).

\subsection{Statistical Analysis}

The obtained data were subjected to multivariate statistical analysis, applying MANOVA to identify significant effects of the application of different concentrations of potassium phosphite on E. citriodora Hook plants subjected to water deficit. Canonical discriminant analysis was performed to determine the contribution of each variable in the discrimination of groups of treatments. In addition, the analysis of phenotypic correlation network was performed to investigate the correlation between variables. Statistical analyses were carried out using algorithms available in the software R 3.4.2 (R Development Core Team, 2017).

\section{Results and Discussion}

The results of the multivariate analysis of variance (MANOVA) with the values of Roy's largest root multivariate test $=1.9073(\mathrm{~F}=5.0068 ; \mathrm{p}=0.0014<0.05)$ showed significant difference between the means of the treatments, revealing dissimilarity between E. citriodora Hook plants for the variables evaluated. The MANOVA analysis model considered a vector of means of the eight variables, as a function of the treatments. In order to study and identify which combination(s) of variables is(are) responsible for the discrimination of the plants, we performed a canonical discriminant analysis (CDA), which allows better interpretation and discussion of the results.

CDA allows the extraction of new variables, not correlated with each other, from the set of original parameters that are able to maximize the separation between the groups of treatments (Sorbolini et al., 2016). The number of functions generated is $\mathrm{T}-1$, and $\mathrm{T}$ is the number of groups of treatment in the study. Thus, the four canonical discriminant functions (CDF) were produced. It can be observed that the four functions explain $100 \%$ of the data variability, but for a better understanding, two discriminant functions which correspond to $89.98 \%$ of variability were used, that is, $72.91 \%$ in the first function $\left(\mathrm{CDF}_{1}\right)$ and $17.07 \%$ in the second function $\left(\mathrm{CDF}_{2}\right)$ (Table 1).

$\mathrm{CDF}_{1}$ showed canonical correlation of 0.6603 , which indicates high association between the variables, whereas $\mathrm{CDF}_{2}$ showed a correlation of $0.3128 . \mathrm{CDF}_{1}$ is always the most important, because it explains greater data variation and correlation of variables. Other researchers observed that, for reliability and satisfactory interpretation of the results, the first two canonical variables need to comprise variation above $80 \%$ of the total contained in the set of parameters analyzed (Cruz, Siqueira, \& Salomão, 2012). 
Table 1. Canonical discriminant analysis for the treatments with different concentrations of potassium phosphite in E. citriodora Hook plants subjected to water deficit

\begin{tabular}{llllllll}
\hline Canonical discriminant function (CDF) & DF & F Approximation & Eigenvalue & Percentage (\%) & Accumulated (\%) & p-value \\
\hline $\mathrm{CDF}_{1}$ & 0.6603 & 32 & 1.2482 & 1.9439 & 72.91 & 72.91 & 0.2198 \\
$\mathrm{CDF}_{2}$ & 0.3128 & 21 & 0.6379 & 0.4552 & 17.07 & 89.98 & 0.8714 \\
$\mathrm{CDF}_{3}$ & 0.1448 & 12 & 0.4431 & 0.1694 & 6.35 & 96.33 & 0.9352 \\
$\mathrm{CDF}_{4}$ & 0.0889 & 5 & 0.4101 & 0.0976 & 3.67 & 100.00 & 0.8364 \\
\hline
\end{tabular}

Canonical discriminant functions can be expressed in equations (Equations 1 and 2), which are linear combinations of the original variables, and each discriminant function can be used to calculate the set of $n$ discriminant scores for each function (Matthew, Lawoko, Korte, \& Smith, 1994).

$$
\begin{aligned}
& \mathrm{Z}_{1}=0.48 \mathrm{~F}_{0}+1.69 \mathrm{~F}_{\mathrm{m}}+1.67 \mathrm{~F}_{\mathrm{v}} / \mathrm{F}_{\mathrm{m}}+2.03 \mathrm{Y}_{\mathrm{II}}-1.71 \mathrm{Y}_{\mathrm{NO}}-1.14 \mathrm{Y}_{\mathrm{NPQ}}+2.75 \mathrm{ETR}-2.75 \mathrm{PROL} \\
& \mathrm{Z}_{2}=-3.01 \mathrm{~F}_{0}-1.32 \mathrm{~F}_{\mathrm{m}}+1.93 \mathrm{~F}_{\mathrm{v}} / \mathrm{F}_{\mathrm{m}}+2.68 \mathrm{Y}_{\mathrm{II}}-1.49 \mathrm{Y}_{\mathrm{NO}}-1.914 \mathrm{Y}_{\mathrm{NPQ}}-0.04 \mathrm{ETR}+2.12 \mathrm{PROL}
\end{aligned}
$$

According to $Z_{1}$ (Equation 1), the variables that most contributed to the discrimination of groups of treatments were the apparent electron transport rate (ETR), with a positive score of 2.75; the effective quantum yield of PSII $\left(\mathrm{Y}_{\mathrm{II}}\right)$, with a positive score of 2.03 , in contrast to the free proline content in the leaves (PROL), with a negative score of -2.75 . As the first function is the most important, it can be affirmed that these variables are the most relevant in the separation of groups of treatments. In $Z_{2}$ (Equation 2), the most important variables were minimum fluorescence $\left(\mathrm{F}_{0}\right)$, with a negative score of -3.01 , in contrast to $\mathrm{Y}_{\mathrm{II}}$, with a positive score of 2.68 , and PROL with a positive score of 2.12. Studies have shown that water stress can cause deleterious effects on the chloroplasts, interfering in photosynthetic efficiency by the inactivation of photosystem II (P680 or PSII) and electron transport chain (Costa, Bressan-Smith, Oliveira, \& Campostrini, 2003). Moreover, the stress caused by lack of water also interferes with the cell metabolism, favoring the synthesis and accumulation of sugars, amines and amino acids, such as proline (Campos et al., 2011). Thus, the variables observed in Equations 1 and 2 as the most relevant for the separation of groups of treatment are consistent with the literature reports for the differentiation between plants that are sensitive and tolerant to water stress.

In the first canonical discriminant function, the most important treatments were the irrigated control treatment and the treatment in which plants were maintained without irrigation after the application of $5.00 \mathrm{~L} \mathrm{c}^{\mathrm{p}}$. ha ${ }^{-1}$ of potassium phosphite, since they had the highest positive means (1.1806 and 1.0487, respectively), in contrast to the treatment in which plants were maintained without application of potassium phosphite and under water deficit (Control + WoI), with a negative mean of -2.1827 . The treatment in which plants were subjected to water deficit after the application of 1.25 L c.p. ha $^{-1}$ of potassium phosphite was the one which most contributed to the second canonical discriminant function, with a mean value of 1.0349 (Table 2).

Table 2. Means of the treatments studied in E. citriodora Hook plants in the first and second canonical discriminant functions

\begin{tabular}{lll}
\hline Treatments & Canonical discriminant 1 & Canonical discriminant 2 \\
\hline Control + WI & 1.1806 & 0.0066 \\
Control + WoI & -2.1827 & -0.5331 \\
$1.25 \mathrm{~L} \mathrm{ha}^{-1} \mathrm{PP}+$ WoI & -0.5316 & 1.0349 \\
$2.50 \mathrm{~L} \mathrm{ha}^{-1} \mathrm{PP}+$ WoI & 0.4851 & 0.1559 \\
$5.00 \mathrm{~L} \mathrm{ha}^{-1} \mathrm{PP}+$ WoI & 1.0487 & -0.6644 \\
\hline
\end{tabular}

Note. WI: with irrigation; WoI: Without irrigation; PP: potassium phosphite.

The results obtained from the first canonical discriminant show that the plants of treatments with application of 5.00 L c.p. ha $^{-1}$ of potassium phosphite, even under water deficit conditions, maintained a photosynthetic performance similar to that of plants in the control treatment with irrigation, in contrast to those of the control treatment without irrigation. Evidence suggests that potassium phosphite application improves the nutritional status of plants and increases their resistance due to greater water retention (Silveira \& Malavolta, 2000). Studies have evaluated the response of Eucalyptus species cultivated under water deficit and potassium phosphite application, showing positive effects on plant resistance to this unfavorable condition. In the experiment 
conducted by Gonçalves, Sousa, and Velini (2015) with application of potassium phosphite in seedlings of $E$. grandis vs. E. urophylla subjected to water deficit, these authors found that the application of this product was important for the reduction of water loss by plants and attenuation of the effects of water stress.

According to the boxplot of the first canonical discriminant function, plants of the control treatment without irrigation were discriminated from those of the other treatments, being directly influenced by the increase of free proline content in the leaves (PROL) and of the variables of quantum yield of regulated dissipation $\left(\mathrm{Y}_{\mathrm{NPQ}}\right)$ and non-regulated dissipation $\left(\mathrm{Y}_{\mathrm{NO}}\right)$ in PSII (Figure 1).

The plants of the control treatment without irrigation exhibited a behavior similar to that observed in other crops subjected to water deficit with respect to free proline accumulation in the leaf tissue (Castro et al., 2007; Alvarenga, 2011). According to Tully, Hanson, and Nelsen (1979), increments in proline content seem to be due to the internal water status of the leaves, because those that most rapidly exhibit symptoms of desiccation are the fastest ones to synthesize and accumulate proline.

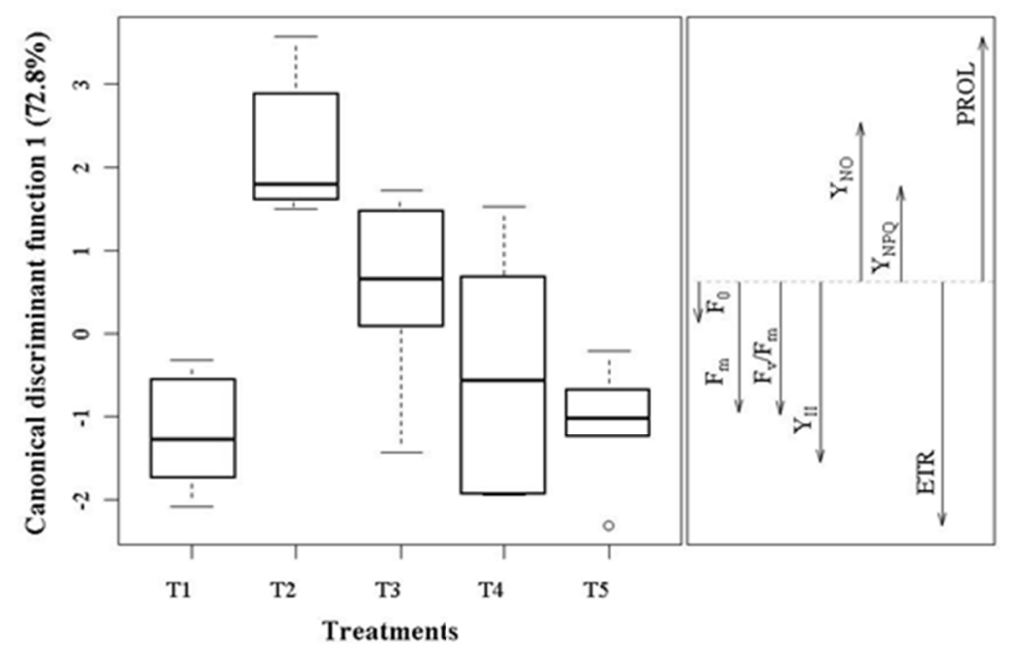

Figure 1. Boxplot graph with the canonical discriminant function 1 for the treatments (T1: control with irrigation; T2: control without irrigation; T3: $1.25 \mathrm{~L} \mathrm{ha}^{-1}$ of potassium phosphite without irrigation; $\mathrm{T} 4: 2.50 \mathrm{~L} \mathrm{ha}^{-1}$ of potassium phosphite without irrigation; T5: 5.00 $\mathrm{L} \mathrm{ha}^{-1}$ of potassium phosphite without irrigation) and parameters evaluated in E. citriodora Hook plants. $\mathrm{F}_{0}$ : minimal fluorescence; $\mathrm{F}_{\mathrm{m}}$ : maximum fluorescence; $\mathrm{F}_{\mathrm{v}} / \mathrm{F}_{\mathrm{m}}$ : potential quantum yield of PSII; $\mathrm{Y}_{\mathrm{II}}$ : effective quantum yield of PSII; $\mathrm{Y}_{\mathrm{NPQ}}$ : quantum yield of regulated dissipation; $\mathrm{Y}_{\mathrm{NO}}$ : quantum yield of non-regulated dissipation; ETR: apparent electron transport rate; PROL: free proline content in the leaves

In relation to PSII, studies have shown that it can be inhibited in plants subjected to water stress, resulting in damage to the photosynthetic apparatus, with consequent reduction of the effective quantum yield of PSII ( $\mathrm{Y}_{\text {II }}$ ) and increase of $Y_{\mathrm{NO}}$. $\mathrm{Y}_{\mathrm{II}}$ corresponds to the fraction of energy that is photochemically converted in the PSII, i.e., it indicates the proportion of light that was absorbed by the chlorophyll associated with PSII used in photochemical activity, being an indicator of photosynthesis (Baker \& Rosenqvst, 2004). The remaining fraction (1- $\left.\mathrm{Y}_{\mathrm{II}}\right)$ constitutes the total quantum yield of all processes of loss, divided into two distinct parameters, $\mathrm{Y}_{\mathrm{NO}}$, which reflects the fraction of energy that is passively dissipated in the form of heat and fluorescence, and $\mathrm{Y}_{\mathrm{NPQ}}$, which consists in the photoprotection induced by light through the thermal dissipation of energy (Klugarmmer \& Schreiber, 2008).

When $Y_{\text {II }}$ values are close to zero at high quantum flux densities, high values of $Y_{N P Q}$ indicate a high photoprotection capacity, whereas high $Y_{N O}$ values reflect the inability of a plant to protect itself against damage by excessive illumination. In plants of the control treatment without irrigation, there was a reduction of $Y_{\text {II }}$ values in comparison to the plants of the other treatments, with consequent increase in $\mathrm{Y}_{\mathrm{NPQ}}$ and $\mathrm{Y}_{\mathrm{NO}}$ (Figure 1), probably caused by the stress due to lack of water. This indicates that, despite the increase in photoprotection induction $\left(\mathrm{Y}_{\mathrm{NPQ}}\right)$, there was also an increase in $\mathrm{Y}_{\mathrm{NO}}$, which reveals the inability of these plants to protect themselves from the damage caused by excess light. 
Plants of the control treatment with irrigation and plants of the treatments with foliar application of the highest concentrations of potassium phosphite $\left(2.50\right.$ and $\left.5.00 \mathrm{~L} \mathrm{c.p.} \mathrm{ha}{ }^{-1}\right)$ prior to the period of water deficit were not separated by the canonical discriminant function 1, showing the highest values for the variables ETR, Y $\mathrm{II}_{\text {, }}$ potential quantum yield of PSII $\left(\mathrm{F}_{\mathrm{v}} / \mathrm{F}_{\mathrm{m}}\right)$ and maximum fluorescence $\left(\mathrm{F}_{\mathrm{m}}\right)$, in contrast with the variables PROL, $\mathrm{Y}_{\mathrm{NO}}$ and $\mathrm{Y}_{\mathrm{NPQ}}$, which showed reduced values in these treatments (Figure 1).

Despite the water deficit, plants treated with foliar application of 2.50 and 5.00 L c.p. ha ${ }^{-1}$ of potassium phosphite did not undergo reduction of ETR in relation to those in the irrigated control treatment (Figure 1), which suggests that the stress caused did not inhibit the transport of electrons in PSII. As previously discussed, there are reports in the literature claiming that various environmental stresses, including water stress, can compromise the events in the thylakoids, causing deleterious effects on chloroplasts and interfering with photosynthesis efficiency. According to Kaiser (1987), under water deficit conditions, part of the inhibition of photosynthesis can be attributed to non-stomatal factors at chloroplast level, mainly caused by problems in electron transport.

The results found corroborate those obtained by Zucareli, Ono, and Krohn (2014) in non-irrigated passion fruit plants, in which they observed a marked reduction of ETR, showing that water stress affected electron transport and, consequently, photosynthesis in these plants.

Plants of the control treatment without irrigation exhibited a reduction in the potential quantum yield of PSII $\left(\mathrm{F}_{\mathrm{v}} / \mathrm{F}_{\mathrm{m}}\right.$ ) (Figure 1), which may have been caused by the stress condition due to water deficit. The $\mathrm{F}_{\mathrm{v}} / \mathrm{F}_{\mathrm{m}}$ ratio is an estimation of the maximum potential quantum efficiency of the photochemical activity of PSII, when all PSII reaction centers are open. This ratio has been widely used to diagnose disturbances in the photosynthetic apparatus caused by environmental and biotic stresses, including water stress, since the reduction of its values indicates damage to PSII reaction centers, related to the reduction of intercellular $\mathrm{CO}_{2}$ concentration, caused by stomatal closure.

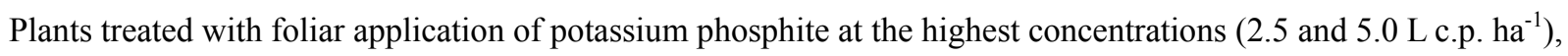
despite the water deficit, were able to maintain the $\mathrm{F}_{\mathrm{v}} / \mathrm{F}_{\mathrm{m}}$ ratio at values similar to those observed in plants of the irrigated control treatment, indicating the resistance of photochemical activity in the primary reactions of photosynthesis even under stress conditions, which probably results from the attenuating effect of the application of potassium phosphite at these doses (Figure 1). In general, the $F_{v} / F_{m}$ values observed in the plants, irrigated or under water deficit, remained within the range from 0.75 to 0.85 suggested by Bolhàr-Nordenkampf et al. (1989) as the range in which the photosynthetic apparatus of the plant is intact. Cruz et al. (2009) observed lower value of $\mathrm{F}_{\mathrm{v}} / \mathrm{F}_{\mathrm{m}}$ ratio $(0.32)$ in citrus cultivars subjected to water stress, which recovered with subsequent irrigation. Low $\mathrm{F}_{\mathrm{v}} / \mathrm{F}_{\mathrm{m}}$ values can be associated with stress intensity and duration, in addition to the characteristics related to plant genotype.

Figure 2 shows the canonical biplot of the variables evaluated in E. citriodora Hook plants, considering the groups of treatments. The canonical biplot is projected by the discrimination of the groups of treatments, in order to study the main variables responsible for their differentiation (González-Martín et al., 2016). The CDA approach is quite straightforward, based on the simple visual analysis of the plane with the projection of the two canonical discriminant functions (Sorbolini et al., 2016). 


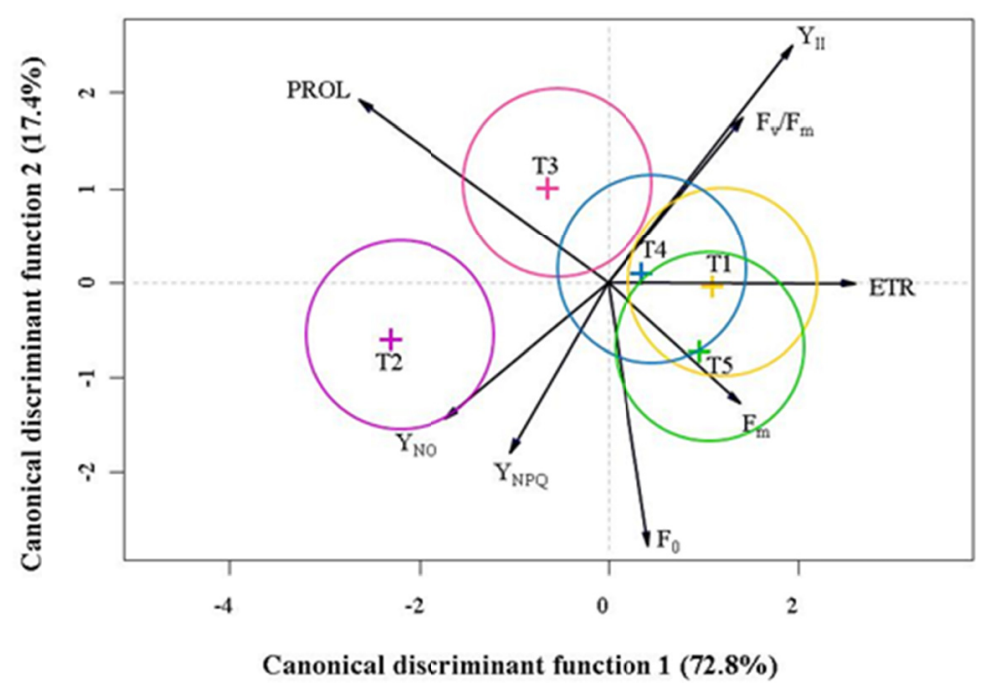

Figure 2. Canonical discriminant biplot for the correlation between treatments with potassium phosphite concentrations (T1: control with irrigation; T2: control without irrigation; T3: 1.25 L c.p. ha ${ }^{-1}$ of potassium phosphite without irrigation; T4: 2.50 L c.p. ha $^{-1}$ of potassium phosphite without irrigation; T5: 2.50 L c.p. ha $^{-1}$ of potassium phosphite without irrigation) and chlorophyll $a$ fluorescence parameters $\left(\mathrm{F}_{0}\right.$ : minimum fluorescence; $\mathrm{F}_{\mathrm{m}}$ : maximum fluorescence; $\mathrm{F}_{\mathrm{v}} / \mathrm{F}_{\mathrm{m}}$ : potential quantum yield of PSII; $\mathrm{Y}_{\mathrm{II}}$ : effective quantum yield of PSII; $\mathrm{Y}_{\mathrm{NPQ}}$ : quantum yield of regulated dissipation; $\mathrm{Y}_{\mathrm{NO}}$ : quantum yield of non-regulated dissipation; ETR: apparent electron transport rate) and free proline content in the leaves (PROL) of E. citriodora Hook plants

This study has five treatments and eight variables evaluated, and the first discriminant function was the one that best differentiated the groups of treatments applied in E. citriodora Hook plants. The axis of the first canonical discriminant function (Can 1) proved to be significantly the most important in the ordering of the effect of the different concentrations of potassium phosphite in eucalyptus plants subjected to water deficit, on the variables studied. On this axis it is possible to observe that the application of potassium phosphite in the plants affects more $\mathrm{Y}_{\mathrm{II}}$ and ETR, with the highest positive scores, and PROL, with the highest negative score (Figure 2).

The canonical discriminant function (Can 1) discriminated plants of the control treatment without irrigation in relation to the other treatments. The confidence ellipses allow for a clear differentiation between the groups. However, plants that received foliar application of potassium phosphite at the highest concentrations $(2.50$ and $5.00 \mathrm{~L}$ c.p. $\mathrm{ha}^{-1}$ ) were in the same group of plants of the irrigated control treatment. The variables which influenced the separation of the control treatment without irrigation from the others were PROL, $Y_{N O}, Y_{N P Q}$ and ETR. It can be observed that in this treatment plants showed the highest values of free proline content in the leaves and quantum yields of regulated and non-regulated dissipation $\left(\mathrm{Y}_{\mathrm{NPQ}}\right.$ and $\left.\mathrm{Y}_{\mathrm{NO}}\right)$, in detriment of the apparent electron transport rate (ETR) (Figure 2). These results are consistent with those reported in the literature, according to which the stress due to water deficit can cause physiological and biochemical alterations in plants, including the reduction of quantum yield of PSII (Silva, Jifon, Silva, \& Sharma, 2007) and photosynthetic rate, besides osmotic adjustment, with increments in the synthesis and accumulation of proline (Campos et al., 2011).

On the other hand, there was no discrimination between the irrigated control treatment and the treatments in which plants were subjected to the highest concentrations of potassium phosphite $\left(2.50\right.$ and $5.00 \mathrm{~L} \mathrm{c}^{\mathrm{p}}$. ha $\left.{ }^{-1}\right)$ under water deficit by the discriminant functions Can 1 and Can 2. The variables ETR, $F_{m}, F_{v} / F_{m}$ and $Y_{I I}$ influenced with high positive values and PROL with low values these three groups of treatments in relation to the others (Figure 2), showing that, despite the water stress, the plants maintained full photosynthetic activity and reduction of free proline content in the leaves. These results confirm the effectiveness of potassium phosphite application at the highest concentrations to attenuate the deleterious effects caused by water stress on $E$. citriodora Hook plants.

Through the second canonical function (Can 2), plants of the treatment with application of $1.25 \mathrm{~L} \mathrm{c.p.} \mathrm{ha}{ }^{-1}$ of potassium phosphite under water deficit were separated from those of the control treatment with irrigation, control treatment without irrigation and the treatment with application of $5.00 \mathrm{~L} \mathrm{c.p.} \mathrm{ha}^{-1}$ of potassium phosphite under water deficit, and the variables responsible for the discrimination were PROL, $\mathrm{Y}_{\mathrm{II}}$ and $\mathrm{F}_{\mathrm{v}} / \mathrm{F}_{\mathrm{m}}$ with high positive values in this treatment, in contrast with the variables $\mathrm{F}_{0}, \mathrm{Y}_{\mathrm{NPQ}}$ and $\mathrm{Y}_{\mathrm{NO}}$. Therefore, plants of the 
treatment with application of $1.25 \mathrm{~L} \mathrm{c.p.} \mathrm{ha}^{-1}$ of potassium phosphite under water deficit showed low values for these variables (Figure 2), indicating that the applied concentration of potassium phosphite $\left(1.25 \mathrm{~L} \mathrm{c.p.} \mathrm{ha}{ }^{-1}\right)$ may not have been sufficient to attenuate the effects of water deficit on these plants.

The phenotypic correlation network provides the intercorrelations between the variables, ranging from -1 to 1 . When the coefficient is close to 1 , it means that there is a high positive correlation between two variables, i.e., one variable tends to increase when the other increases. Values close to zero indicate a weak correlation, whereas values close to -1 indicate that the variables have a high negative correlation, causing reduction in one variable with the increase in the other. Thus, it can be concluded that there is evidence of correlation between the variables, indicating that the use of multivariate analysis techniques is appropriate for this study.

In the phenotypic correlation network, the relative density and color of the bands indicate the strength of the Pearson correlation; green color indicates a positive correlation and red color indicates a negative correlation. The phenotypic correlation between the variables evaluated showed that the significantly and positively correlated variables $(P<0.0001)$ were $Y_{\text {II }}$ and ETR $(r=0.66 ; p=0.0001), F_{m}$ and $F_{v} / F_{m}(r=0.48 ; p=0.0075)$, $\mathrm{F}_{0}$ and $\mathrm{F}_{\mathrm{m}}(\mathrm{r}=0.47 ; \mathrm{p}=0.0087)$, whereas the variables $\mathrm{Y}_{\mathrm{II}}$ and $\mathrm{Y}_{\mathrm{NPQ}}(\mathrm{r}=-0.84 ; \mathrm{p}=0.0001), \mathrm{Y}_{\mathrm{NPQ}}$ and $\mathrm{ETR}(\mathrm{r}=$ $-0.52 ; p=0.0034)$ and $F_{0}$ and $F_{v} / F_{m}(r=-0.49 ; p=0.0397)$ were negatively correlated (Figure 3$)$. These results indicate that the effective quantum yield of PSII $\left(\mathrm{Y}_{\mathrm{II}}\right)$ increases with the increase of electron transport rate. $\mathrm{Y}_{\text {II }}$ indicates the fraction of energy absorbed by the chlorophyll associated with PSII that was used in photochemical activity and, as such, informs the quantity of electrons transported, being an indicator of photosynthesis (Lichtenthaler, Buschmann, \& Knapp, 2005). In plants of the control treatment without irrigation, $\mathrm{Y}_{\mathrm{II}}$ decreased on average by $25 \%$ when compared to the control treatment with irrigation, whereas in treatments with foliar application of potassium phosphite, the maximum reduction of $\mathrm{Y}_{\text {II }}$ was approximately $12 \%$. Conversely, the reduction in $\mathrm{Y}_{\mathrm{II}}$ caused an increase in the quantum yield of regulated dissipation $\left(\mathrm{Y}_{\mathrm{NPQ}}\right)$. According to Klughammer \& Schreiber (2008), reductions in $Y_{\mathrm{II}}$ values induce the increase of $\mathrm{Y}_{\mathrm{NO}}$ and $\mathrm{Y}_{\mathrm{NPQ}}$, and the increase in $\mathrm{Y}_{\mathrm{NPQ}}$ is an indication of a high photoprotection capacity.

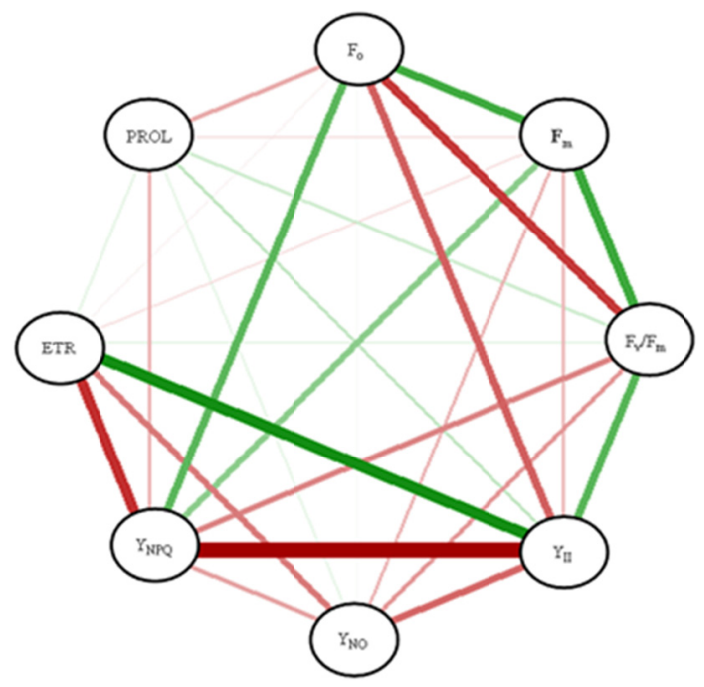

Figure 3. Phenotypic correlation network of E. citriodora Hook plants subjected to application of different concentrations of potassium phosphite and to water deficit. Red and green lines represent negative and positive correlations, respectively. Line width is proportional to the strength of the correlation. Parameters evaluated in

plants: minimum fluorescence $\left(\mathrm{F}_{0}\right)$, maximum fluorescence $\left(\mathrm{F}_{\mathrm{m}}\right)$, potential quantum yield of PSII $\left(\mathrm{F}_{\mathrm{v}} / \mathrm{F}_{\mathrm{m}}\right)$, effective quantum yield $\left(\mathrm{Y}_{\mathrm{II}}\right.$ ) q quantum yield of regulated dissipation $\left(\mathrm{Y}_{\mathrm{NPQ}}\right)$, quantum yield of non-regulated dissipation $\left(\mathrm{Y}_{\mathrm{NO}}\right)$ and free proline content in the leaves

\section{Conclusions}

$>$ There is evidence of correlation between the variables evaluated, indicating that the use of multivariate analysis techniques was adequate for the analysis of this data set;

$>$ E. citriodora Hook plants of the control treatment without irrigation responded to the water deficit conditions with inhibition of the potential and effective quantum yields of photosystem II and electron transport 
chain, and increase of PSII quantum yields of regulated and non-regulated dissipation and free proline content in the leaves;

> Plants which received foliar application of potassium phosphite at the highest concentrations, even under water deficit, preserved the photosynthetic activity and free proline content in the leaves with values equal to those observed in the irrigated control treatment;

$>$ Plants of the control treatment without irrigation showed a reduction in the potential quantum yield of PSII, but its value of 0.81 remained within the range suggested as that in which the photosynthetic apparatus of the plant is intact.

\section{References}

Alvarenga, I. C. A. (2011). Prolina livre em alecrim-pimenta sob estresse hídrico antes da colheita. Revista Brasileira de Plantas Medicinais, 13, 539-541. https://doi.org/10.1590/S1516-05722011000500006

Baker, N. R., \& Rosenqvst, E. (2004). Applications of chlorophyll fluorescence can improve crop production strategies: An examination of future possibilities. Journal of Experimental Botany, 55(403), 1607-1621. https://doi.org/10.1093/jxb/erh196

Bates, L. S., Waldren, R. P., \& Teare, I. D. (1973). Rapid determination of free proline for water-stress studies. Plant and Soil, 39(1), 205-207. https://doi.org/10.1007/BF00018060

Bilger, W., Schreiber, U., \& Bock, M. (1995). Determination of the quantum efficiency of photo system II and of non-photochemical quenching of chlorophyll fluorescence in the field. Oecologia, 102, 425-432. https://doi.org/10.1007/BF00341354

Bolhàr-Nordenkampf, H. R., Long, S. P., \& Baker, N. R., Öquist, G., Schreider, U., \& Lechner, E. G. (1989). Chlorophyll fluorescence as probe of the photosynthetic competence of leaves in the field: A review of current instrument. Functional Ecology, 3, 497- 514. https://doi.org/10.2307/2389624

Campos, M. K. F., Carvalho, K. de, Souza, F. S. de, Marur, C. J., Pereira, L. F. P., Besplahok Filho, J. C., \& Vieira, L. G. E. (2011). Drought tolerance and antioxidant enzymatic activity in transgenic 'Swingle' citrumelo plants over-accumulating proline. Environmental and Experimental Botany, 72(2), 242-250. https://doi.org/10.1016/j.envexpbot.2011.03.009

Castro, D. da S., Santos, A. O. dos, Lobato, A. K. da S., Gouvêa, D. D. S., Oliveira Neto, C. F. de, Cunha, R. L. M. da, \& Costa, R. C. L. da. (2007). Concentrações de prolina e carboidratos solúveis totais em folhas teca (Tectona grandis L.f) submetida ao estresse hídrico. Revista Brasileira de Biociências, 5, 921-923.

Costa, E. S., Bressan-Smith, R., Oliveira, J. G., \& Campostrini, E. (2003). Chlorophyll a fluorescence analysis in response to excitation irradiance in bean plants (Phaseolus vulgaris L. and Vigna unguiculata L. Walp) submitted to high temperature stress. Photosynthetica, 41, 77-82. https://doi.org/10.1023/A:102586042

Cruz, C. D., Regazzi, A. J., \& Carneiro, P. C. S. (2012). Modelo biométrico aplicado ao melhoramento genético. Viçosa: UFV.

Cruz, M. C. M., Siqueira, D. L., Salomão, L. C. C., \& Cecon, P. R. (2009). Fluorescência da clorofila a em folhas de tangerineira 'Ponkan' e limeira ácida 'Tahiti' submetidas ao estresse hídrico. Revista Brasileira de Fruticultura, 31, 896-901. https://doi.org/10.1590/S0100-29452009000300037

D’Angiolella, G. L. B., Castro Neto, M. T., \& Coelho, E. F. (2000). Tendências climáticas para os Tabuleiros Costeiros da região de Cruz das Almas, Bahia. Revista Bahia Agrícola, 4, 14-16.

Gonçalves, K. S., Sousa, A. de P., \& Velini, E. D. (2015). Aplicação de reguladores vegetais e de fosfito de potássio em mudas de eucalipto submetidas à deficiência hídrica. Irriga, 20(2), 273-285. https://doi.org/ 10.15809/irriga.2015v20n2p273

González-Martín, M. I., Vicente-Tavera, S., Revilla, I., Vivar-Quintana, A. M., González-Pérez, C., Hernández Hierro, J. M., \& Lobos-Ortega I. (2016). The role of the canonical biplot method in the study of volatile compounds in cheeses of variable composition. Grasas y Aceites, 67(1), 1-8. https://doi.org/10.3989/ gya.0250151

IBÁ (Indústria Brasileira de Árvores). (2017). Relatório IBÁ 2017. Retrieved from http://iba.org/images/shared/ Biblioteca/IBA_RelatorioAnual2017.pdf

Kaiser, W. (1987). Effects of water deficit on photosynthetic capacity. Physiology Plantarum, 71, 142-149. https://doi.org/10.1111/j.1399-3054.1987.tb04631.x 
Klughammer, C., \& Schreiber, U. (2008). Complementary PSII quantum yield calculated from simple fluorescence parameters measured by PAM fluorometry and saturation pulse method. PAM Application Notes, 1, 27-35.

Kramer, D. M., Johnson, G., Kiirats, O., \& Edwards, G. E. (2004). New fluorescence parameters for the determination of QA redox stat and excitation energy fluxes. Photosynthesis Research, 79, 209-218. https://doi.org/10.1023/B:PRES.0000015391.99477.0d

Lichtenthaler, H. K., Buschmann, C., \& Knapp, M. (2005). How to correctly determine the different chlorophyll fluorescence parameters and the chlorophyll fluorescence decrease ratio RFd of leaves with the PAM fluorometer. Photosynthetica, 43(3), 379-393. https://doi.org/10.1007/s11099-005-0062-6

Malaquias, J. B., Ramalho, F. S., Dias, C. T. dos S., Brugger, B. P., Lira, A. C. S., Wilcken, C. F., ... Zanuncio, J. C. (2017). Multivariate approach to quantitative analysis of Aphis gossypii Glover (Hemiptera: Aphididae) and their natural enemy populations at different cotton spacings. Nature, 7(41740). https://doi.org/10. 1038/srep41740

Martinazzo, E. G., Silva, D. M., Bianchi, V. J., \& Bacarin, M. A. (2012). Fluorescência da clorofila a em plantas de pessegueiro da cultivar maciel enxertada sobre diferentes porta-enxertos. Revista Brasileira de Fruticultura, 34, 678-685. https://doi.org/10.1590/S0100-29452012000300005

Matthew, C., Lawoko, C. R. O., Korte, C. J., \& Smith, D. (1994). Application of canonical discriminant analysis, principal component analysis, and canonical correlation analysis as tools for evaluating differences in pasture botanical composition. New Zealand Journal of Agricultural Research, 37(4), 509-520. https://doi.org/10.1080/00288233.1994.9513090

Nojosa, G. B. de A., Resende, M. L. V., \& Resende, A. V. (2005). Uso de fosfitos e silicatos na indução de resistência. In L. Cavalcanti, R. M. Di-Piero, S. F. Pascholati, M. L. V. de Resende, \& R. da S. Romeiro (Eds.), Indução de resistência em plantas a patógenos e insetos (p. 263). Piracicaba: FEALQ.

R Core Team. (2017). R: A language and environment for statistical computing. Vienna, Austria: R Foundation for Statistical Computing. Retrieved from http://www.R-project.org

Roy, S., Lavine, J., Chiaromonte, F., Terwee, J., VandeWoude, S., Bjornstad, O., \& Poss, M. (2009). Multivariate Statistical Analyses Demonstrate Unique Host Immune Responses to Single and Dual Lentiviral Infection. Plos One, 4(10), e7359.

Silva, M. de A., Jifon, J. L., Silva, J. A. G. da, \& Sharma, V. (2007). Use of physiological parameters as fast tools to screen for drought tolerance in sugarcane. Brazilian Journal of Plant Physiology, 19(3), 193-201. https://doi.org/10.1590/S1677-04202007000300003

Silveira, R. L. V. A., \& Malavolta, E. (2000). Nutrição e adubação potássica em Eucalyptus. Informações Agronômicas, 91, 1-12.

Sorbolini, S., Gaspa, G., Steri, R., Dimauro, C., Cellesi, M., Stella, A., ... Macciota, N. P. P. (2016). Use of canonical discriminant analysis to study signatures of selection in cattle. Genetics Selection Evolution, 48, 58. https://doi.org/10.1186/s12711-016-0236-7

Stewart, S., Ivy, M. A., \& Anslyn, E. V. (2013). The use of principal component analysis and discriminant analysis in differential sensing routines. Chemical Society Reviews, 43, 70-84. https://doi.org/10.1039/ C3CS60183H

Tully, R. E., Hanson, A. D., \& Nelsen, C. E. (1979). Proline Accumulation in Water-stressed Barley Leaves in Relation to Translocation and the Nitrogen Budget. Plant Physiology, 63, 518-523. https://doi.org/10.1104/ pp.63.3.518

Zucareli, V., Ono, E. O., \& Krohn, N. G. (2014). A enxertia na cultura do maracujazeiro: Aspectos Anatômicos, Bioquímicos e Fisiológicos. Journal of Agronomic Sciences, 3, 98-113.

\section{Copyrights}

Copyright for this article is retained by the author(s), with first publication rights granted to the journal.

This is an open-access article distributed under the terms and conditions of the Creative Commons Attribution license (http://creativecommons.org/licenses/by/4.0/). 